inOedia $\quad \begin{aligned} & \text { InMedia } \\ & \text { The French Journal of Media Studies }\end{aligned}$

7.2. $\mid 2019$

Documentary and Entertainment

\title{
The BBC and Disaster Films: From Education to Entertainment
}

\section{Georges Fournier}

\section{(2) OpenEdition \\ 12 Journals}

\section{Electronic version}

URL: http://journals.openedition.org/inmedia/1766

DOI: 10.4000/inmedia.1766

ISSN: 2259-4728

\section{Publisher}

Center for Research on the English-Speaking World (CREW)

\section{Printed version}

Date of publication: 15 December 2019

\section{Electronic reference}

Georges Fournier, "The BBC and Disaster Films: From Education to Entertainment", InMedia [Online] 7.2. | 2019, Online since 02 December 2019, connection on 26 January 2021. URL: http:// journals.openedition.org/inmedia/1766 ; DOI: https://doi.org/10.4000/inmedia.1766

This text was automatically generated on 26 January 2021.

(C) InMedia 


\title{
The BBC and Disaster Films: From Education to Entertainment
}

\author{
Georges Fournier
}

\section{Introduction}

1 The early years of the twenty-first century witnessed the production of TV films based on disaster scenarios, films both tragic in their denouement and anticipatory in their intentions. Public television experimented with this formula in Daniel Percival's Smallpox 2002: Silent Weapon, a film broadcast by BBC2 in early 2002, a few months after the September 11 attacks. This tragedy, which acted as a catalyst for all manner of fears, fostered many anticipatory programmes, among which the If ... series. As Simon Chinn $^{1}$ explained ${ }^{2}$, fiction can anticipate reality, and Smallpox 2002: Silent Weapon was commissioned before the tragedy of September 11 . Yet, the latter was the climax of a wave of terrorist attacks against civilians, which has continued ever since ${ }^{3}$, and which has inspired BBC productions.

2 Smallpox 2002: Silent Weapon was a unique and daring assignment undertaken by the BBC and which was carried out against a backdrop of scathing criticisms for its catastrophic dimension. According to critics, the choice made by the Corporation was all the more surprising as this production did not fall within the remit of quality television by which the $\mathrm{BBC}$ has always claimed to abide and it was intended to elicit emotional rather than intellectual responses.

3 Nevertheless, this type of production represented a safe way for the Corporation to combine its initial remits - educating, instructing, and informing the population ${ }^{4}-$ with more recent ones, such as the need to rally large audiences to compete with privately owned channels. These programmes are part of a policy designed to facilitate the renewal of the licence-fee funding, ${ }^{5}$ which represented $76 \%$ of the $£ 5$ billion budget in 2018, allowing the corporation to remain free from advertisements, shareholders, and private interests. Considering that issues related to the renewal of the fee intensify as the end of the contract draws closer, the BBC's choice, from 2002 onwards, to opt for 
programmes that combine potentially large audiences with the education and protection of the population can be interpreted with the 2006's licence fee renewal in mind. The publicity given to this type of programme by the U.S. President himself, G.W. Bush, ${ }^{6}$ along with the exceptionally high audience rate garnered by the If ...series, ${ }^{7}$ show that, with these new creations, the Corporation achieved something of a master stroke on which it intended to rely to maintain its monopoly over the licence fee well into the twenty-first century.

4 This paper analyses how the BBC used disaster docudramas ${ }^{8}$ to try to adjust to the constraints imposed on it by the Royal Charter. How far did they help it compete with the private sector, which, at the turn of the century, reached all-time high audience records following the inception of reality-TV? ${ }^{9}$ Going back to the origins of the genre, with The War Game (1965) by Peter Watkins, will provide insight into how the BBC, recently, had to renege on its original remits which were to promote programmes that would document viewers on current issues in a challenging way.

5 A diachronic approach of recent public channel programmes should highlight the irony of the success of Smallpox (2002), The Day Britain Stopped (2003) and Dirty War (2004), when considered in the context of the censorship imposed on Peter Watkins's 1965 film. What place is there for reality, for thought-provoking and innovative ideas in films designed for a media seen nowadays mainly as a source of entertainment?

6 Finally, an examination of the If ... series, broadcast by BBC2 in 2003, will provide answers as to how the broadcasting public sector has recently managed to prove successful in fulfilling its initial remits: informing viewers in an attractive way.

\section{The War Game versus The Day Britain Stopped: from distance to hypnotism}

7 The early days of broadcasting bore witness to some cases of censorship and Peter Watkins's The War Game (1965) was almost indefinitely postponed ${ }^{10}$ for fear that a disaster programme would cause panic among viewers, the way Orson Welles's 1938 radio broadcast of H.G. Wells's The War of the Worlds had caused panic among U.S. listeners. That was, at least, one of the reasons given by the BBC officials at the time, the true motive ${ }^{11}$ being the fear of a massive consensus, among the population, against the use of nuclear power for military purposes. Forty years later, disaster films proved a bonanza for the public service broadcaster which cashed in on their success to boost its audience ratings.

Most of the scenarios of the disaster films commissioned by the BBC from 2002 onwards have been founded on scientific data, the most famous ones being Smallpox (2002), The Day Britain Stopped (2003) and Dirty War (2004). In the context of an increase in terrorist attacks, on a global scale, the large number of productions dealing with this sensitive issue helped increase the belief in an unavoidable threat in the short to medium term future. Yet, their main shortcoming was a trivialisation of issues, unlike Peter Watkins's The War Game, which was designed to make up for the government's improvidence and to warn the population about the effects of a nuclear attack on Britain, the film's chronology spanning the impending threat, the actual explosion, and its aftermath.

Despite an aesthetic that hinges on all the tricks offered by modern cinematic technologies, The Day Britain Stopped is, in many respects, a copy of The War Game, which 
was highly experimental with its non-professional actors, its use of hand-held cameras, and its loosely-scripted scenario. Gabriel Range, the director of The Day Britain Stopped, went so far as to name one of his characters Pauline Watkins (Prue Clarke) as a thinly disguised reference to Peter Watkins himself. Pauline Watkins is a major character in this story and the death of her daughter - never seen but referred to as Charlie Watson - in an accident that caused a truck to overturn and start a chain of tragic events, turns her into the main witness of the chaos that happens on that day on the M25 motorway. Yet, the most obvious point both films share is the choice of a ubiquitous voice-over, manly and learned, that, in both cases, is used as a tool to convey the consequences of events that are presented in advance. The voice-over carefully arranges and ordains the viewers' perception; it rationalises the course of events and claims that the images are of "major incidents turning into a national disaster". Moreover, in The Day Britain Stopped, the voice-over delivers comments, which are strangely reminiscent of the narrative choices made by Peter Watkins in The War Game, in so far as, in both cases, things to happen are prophesies, rendering them ineluctable in the process.

10 Yet, unlike Peter Watkins's The War Game, which explored an apocalyptic situation based on geopolitical data that informed the British population of the possible tragic outcomes of political decisions, The Day Britain Stopped corresponds to an anxiety-type of simulation that was originally intended to be more entertaining, thus garnering a large audience, than informative. Although all the British viewers could easily identify the places mentioned, they were confronted with a scenario that was both totally fictional and anticipatory, having no root in their then present time: the action was supposed to take place at the end of 2003, on 19 December precisely, while the film was released on 13 May, of the same year, with a series of events that were not related in any way to what was going on nationally at the time.

11 While the narrator of The War Game spells out the future consequences of nuclear attacks on civilians, whether sociological, phenomenological, or political, the narrator of The Day Britain Stopped comments on what is actually going on: his words are descriptive, they are tautological in so far as they paraphrase the images. This lack of perspective regarding what may happen in the near future pervades the whole film. In The War Game, Peter Watkins constantly breaks the mesmerising effects of realism ${ }^{12}$ to encourage viewers to reflect on TV, as a medium, and on the filmic material; the disruptions he introduces are meant to avoid engulfing viewers in a stream of images that would make them think of his film as entertainment rather than as a political plea against the military use of nuclear energy, and as a plea for the political use of film and television. While Peter Watkins's jump cuts serve to break the realistic effect to focus the viewers' attention on the nature of the filmic material and on TV as a medium, the editing, in The Day Britain Stopped, is part of a rhythm that alternates long shots, extreme close-ups, and foci on details, giving the film a syncopated dimension, like chaos itself. The overall effect recalls the urgency of situations of crisis which, as far as the filmic process is concerned, is also rendered by blurred images ensuing from brisk movements preventing the immediate adjustment of the length of the focal lenses. Furthermore, frightening images, which saturate the screen, do not provide the distance that is required for reflection and analysis, so that the violence of the visible, similar in its effects to the regime of shock and awe, has no other function than the obliteration of reason. 

these films, which rest on the editing of fleeting images. Visually, this impression comes from the succession of whip pans and zoom blur-effects, which characterize disaster films. Similarly, the use of fade-outs makes each image dissolve into the next, giving a feeling of inescapable succession between events which, consequently, become closely connected and which compound to generate a feeling of inevitability. A feeling that can also be found in the chronology of the events which begins with the train accident, leads to the unionist's decision to go on strike, and then to traffic jams and accidents on the motorways. These incidents result in flight delays, and finally a collision between two planes. Gabriel Range opts for a form of representation centred on high frame rates, on deafening sounds and on violent and aggressive colours, which creates a saturation effect likely to generate inhibition. The director depicts the crisis as it is unfolding, which supports the feeling of inevitable impending doom. Unlike Peter Watkins, who opted to experiment with new forms of documentary, extensively resorted to changing viewpoints and close-ups - particularly ones of faces expressing fear and dismay - choosing to disrupt viewers and provoke reflections on images and their relationship to reality, Gabriel Range mimicked the aesthetics of news reports to which TV viewers are accustomed through the daily news.

While Peter Watkins imposed the distance that is required for analysis, Gabriel Range introduced a closeness that induces empathy and leads viewers to be completely absorbed by the disaster scenario that is presented to them. While, in the 1960s, Peter Watkins's film anticipated the supremacy of TV journalism, The Day Britain Stopped mimics journalistic aesthetics to capture the attention of viewers better with aweinspiring images. While the former had documentation and information as the main motive, the latter has entertainment in mind.

14 bodies that pass close to the camera lens, increasing the feeling of urgency and chaos. However, Peter Watkins remains faithful to the principle of identification and he is very explicit about the nature of the images he employs, even when he decides to use negatives to give the impression of bodies seen in the blinding light of a nuclear explosion. Any image is thus always easily and immediately identifiable, and viewers may, at any time, recognize the fictional world as the one they live in. The plot moves along a web of catastrophes that all converge on the impression of inevitability, of inescapability.

In Gabriel Range's film, reality is digitalised and many shots display the digital mapping of the places mentioned, a stylistic device, which the filmmaker uses over and over again; this complete de-realization of the environment also contributes to making eerie that which is familiar. The omniscient narrator guides the viewers' perception, reducing it or enlarging it at will. De-realization is also enhanced by images from CCTV cameras that show the comings and goings of passengers at Heathrow Airport or the traffic from stretches of the highway. The political implications of these stylistic devices need to be examined to determine how, forty years after The War Game, a docudrama, designed to inform viewers and document events, BBC disaster films are now mainly intended to provide entertainment. 


\section{The political scope of disaster scenarios}

16 The major difference between recent disaster films for television and Peter Watkins's The War Game is found, first of all, in the original intention. The War Game was intended as a political film criticising the government both for the possible use of nuclear weapons and for the lack of measures taken to protect the population, as explained by the filmmaker himself on the official site dedicated to the film:

BY LATE 1964 Harold Wilson's newly elected Labour Government had already broken its election manifesto to unilaterally disarm Britain, and was in fact developing a full-scale nuclear weapons programme, in spite of wide-spread public protest. [...]

As part of my research, I had sent a letter to the Home Office inquiring how many hospital beds, etc. the Civil Defence would be able to provide following an all-out nuclear strike on the UK. ${ }^{13}$

Peter Watkins's main intention was not to brace British citizens for a nuclear attack by indicating what was desirable for them to do: his film was primarily intended as a form of political electroshock to get people to put pressure on the government to reverse its position on the military usage of nuclear power. Conversely, The Day Britain Stopped, Smallpox, Dirty War and the If ... series, all aired by the BBC at the turn of the twenty-first century, can be seen as a form of prescriptive television that aims to warn people of potential hazards and to inform them on how to behave accordingly. The Day Britain Stopped, for instance, sides with the authorities against individuals: behind the allpervasive threat at the heart of Gabriel Range's film stands the conjunction of both corporatist and personal interests. The message is unequivocal: the blame is to be put on the trade-unionists who chose to hold the whole country hostage on one of the busiest days of the year - Black Friday ${ }^{14}$ - although, incidentally, the country had already been plagued by the chaos of a completely deregulated market economy. At first sight, fate stands at the centre of this scenario that is built around a series of unstoppable disasters. Yet, gradually, fate gives way to the pervasive feeling that all this is due to an enemy that comes from within, an enemy both omnipresent and threatening. The Day Britain Stopped initiated TV productions that have hinged on the notion of the invisible enemy-from-within who cannot be identified, rendering the threat ever stronger. ${ }^{15}$

The BBC's decision to support Gabriel Range's film can be seen in the light of an intense competition for audience ratings, making the monopoly of the broadcasting public sector, over the licence fee, the target of widespread criticisms. Yet, this explanation does not exonerate the $\mathrm{BBC}$ for the production of a film that can be seen as reactionary on several counts, as when the journalist blames the chaos on trade unions: for him, they stand behind the strikes that paralyzed the country and brought about a series of catastrophes in which dozens of people perished. Images that can be mistaken for documentary footage increase the plausibility of the situation and of the message that accompanies it. During the live television news coverage, a reporter violently addresses Mick Rix, the then leader of the Associated Society of Locomotive Engineers and Firemen's union (ASLEF) ${ }^{16}$ : "Mr Rix, how does it feel to bring the country to a standstill?" The attack is all the more violent as there appears on the screen a picture of the face of the unionist accompanied by a signboard on which are written apologies to users about the inconvenience caused by the strike and which do not come from the trade unionist himself, but which stand right behind him. The deviousness of the attack 
on the trade unionist lies in the juxtaposition of the signboard next to the photograph of his face and the message is unambiguous: he did not apologize, although viewers are led to feel that it is what he should have done. The use of the image of the unionist stands in sharp contrast with the use of fictional characters for other roles, not only the reporter but also the Junior Minister of Transport, Tom Walker (Eric Carter). As for newsreaders, they accepted to take part in this docudrama and acted out their part, as professionals, in front of the camera.

The filmmaker emphasises the trade unionist's responsibilities; it is all the less justified as he does not mention the true economic and political reasons which led to the mobilization that erupted into chaos. First among these is the deregulation of the transportation sector about which only anecdotal remarks are made. At the beginning of the fiction film, the voice-over notes that "decades of neglect have led to a day of disasters", something that, incidentally, is echoed by a policeman when he mentions the lack of information on road works in progress. Similarly, an aviation expert, a doomsayer of air disasters, underlines the threat posed to aviation by savings made on fuel tanks filled to a minimum which, in case of diversion, can prove fatal. Finally, the same speaker mentions the specificity of the UK's transport investment problem, which is echoed precisely at the end of the film by the Junior Minister of Transport himself: "Unlike other European countries, we do not invest enough public money in transport. In no way could we have foreseen this chain reaction."

With this declaration from a character who voices the official stance, public television serves as a mouthpiece for the authorities who, ever since the September 11 attacks, have used fiction on prime-time TV to acclimatise the population to the probable and complete disorganization of the country, in the context of troubled international politics. Unfortunately, all these elements add up to a series of anecdotes; the true political message lies in the broadcasting of the programme itself, which is not political in the sense that it is designed to make things move forward, to make society progress, but in the fact that it is reactionary: the staging and broadcasting of this type of disaster movie on a public TV channel stands as a warning from policy makers who can then claim not to be accountable, whatever the catastrophe. It is a testimony of their impotence; it stands as a forewarning of their refusal to be held responsible. ${ }^{17}$

Unlike the docudramas of the mid-1960s, this type of programming is rife with pathos and voyeurism. In The Day Britain Stopped, no political analysis is provided for either the reasons behind the drivers' strike or the lack of coordination among the managers of the road network. The TV viewer is inundated with images from the news which are recycled over and over again and which the director fails to enrich semantically. To quote a phrase coined by Gilles Deleuze ${ }^{18}$ this is an example of the "civilization of the cliché" ${ }^{19}$, the political implication being mainstream ideological conformism. This is to be understood as the filmmaker's will to abide by the general iconic codes and conventions promoted by TV and cinema and to shun any attempts either to be innovative or to try and get viewers to ponder over both message and image, as Peter Watkins would do when introducing disruptions. ${ }^{20}$

From a political point of view these TV films tend to disempower viewers, who are also citizens, by instilling in them the idea that the best strategy is to be passive and not to interfere with the professionals. The message that is conveyed is not to impede relief but to not get in the way of those who know best. It strengthens the feeling of fatalism that reinforces the citizens' belief that they are living in a world whose complexity 
exceeds their understanding and which they are condemned to undergo. This type of programme represents the entertaining aspect of disempowerment; it corresponds to the political infantilization of citizens that benefits oligarchies and which Margaret Thatcher's motto "There is no alternative" aptly encapsulated.

\section{The dramaturgy of destiny as the alpha and the omega of disaster films}

With this type of programme, the BBC moved from its status as "public-service television" to that of "government television", a TV that is not supposed to displease its creditors, especially in the early 2000s with the political turmoil caused by David Kelly's revelations on Radio 4 about the Iraqi affair ${ }^{21}$ : being accused of journalistic amateurism, the BBC's director-general, Greg Dyke, resigned and an in-house school of journalism was set up. The decision was then taken not to provide political analyses of issues but to stage them in a melodramatic way; individualizing issues and difficulties enables empathy but makes rigorous political approaches inoperative. The narrative then shifts the debate about the management, or rather mismanagement, of societal issues from the public, social and political spheres to the personal one, depriving them, in the process, of their political dimension. It gives social issues a melodramatic dimension, that of the individual against the forces of fate. This is a classic trope which is emblematic of modern TV and which consists in operating a transfer from the collective to the personal: the political crisis becomes an individual crisis and the catastrophe, in the sense of an accident that causes the deaths of many people, becomes the tragedy of a few, whom viewers soon become familiar with; a trope best suited to generate empathy. Likewise, individualising issues means absolving politicians who cannot be held responsible. Conversely, maintaining a political approach to catastrophes would force the ones holding office to bear full responsibility for both causes and consequences.

Staging social issues and representing them in a catastrophic way means depoliticizing them: in this type of film, the sensational becomes the driving force that obscures both the social and the political dimensions of issues. Viewers are confronted with some sort of live coverage, which offers no means to understand the events in a rational way.

The personalisation of issues associated with disaster movies requires transference and pathos, something which makes it difficult for viewers to grasp these very issues intellectually. Dissociating them from both their political and historical contexts to give them a personal dimension means reducing them to shocking images, images intended to impress. It means disguising reality and concealing responsibilities; it means turning the errors and shortcomings of policy makers into accidents, which were impossible for them to prevent, despite their supposed goodwill.

The feeling of fatum, of inevitability, is all the greater when, as in the case of The Day Britain Stopped, disaster sequences follow one another closely thereby creating a cumulative and domino effect. Politicians, like the Junior Minister of Transport, in Gabriel Range's film, can then logically and legitimately declare: "We could not do much." Surprisingly, even the extraordinary and the unthinkable become plausible and logical; a process of acceptance of the improbable gradually sets in. There follows a naturalization $^{22}$ of the exceptional, and tragedies unfold, one after the other, inexorably, without awakening the slightest form of disbelief from viewers. Tragedies 
gradually overshadow the failures of politicians: chaos could not be prevented and responsibilities are dissolved in the inevitability of a scenario that actually stems from improvidence and negligence.

As explained by Gérard Leblanc, a film theorist: "The State needs a chaotic representation of the world and a tragic view of current events because it is unable to completely prevent the constant return of disarray"23 The naturalization of disasters increases their tragic dimension: the responsibility for what is happening is then not the result of a political mistake but the one of random and indiscriminate fatum.

Naturalizing the tragic consequences of a social conflict by putting them on the same level as those from a natural catastrophe, like an earthquake, means evading any attempt at understanding them. Fictionalising these issues means obscuring them still further by failing to provide the necessary distance that is required to put them in perspective. The impact, even more than the reasons behind them, is highlighted and dissected but not analysed. By separating effects from causes, an impression of inevitability, in all its brutality and indiscrimination, is gradually instilled in the viewers' minds and eventually prevails. By ignoring the historical and political aspects of events, all the catastrophes are put on the same level, whether natural or not, whether ineluctable or not, and responsibilities are diluted in a general feeling of acceptance, whatever the nature of the events since they result from the will of destiny. The weaker the body politic, the more fate, irrationality and cosmic order are invoked, all of which are forces beyond man's control and, as a result, the more the viewers are likely to look for meaning in the consequences rather than in the origins. The unfolding of a tragic narrative is designed to replace explanations. The naturalization of social and political issues is a process of dumbing down, because it replaces meaning by observation; it is a form of censorship that reduces the disaster to its final phase, which involves avoiding considerations about the causes and so exonerates the responsible parties.

The impact of this type of programme would not be so powerful without the realistic aesthetics and its fascinating dimension, in the wake of which comes deception: all the filmic devices used, from the choice of frames - from extreme close-ups to extreme long shots - to the carefully arranged montage, are chosen to give viewers the impression of live coverage, which these fiction films are not. This type of production corresponds to the BBC's disengagement from the political sphere in favour of reality TV through disaster films that generate high ratings because they tap heavily into sensationalism and voyeurism. However, it is necessary to qualify this cynical view of the media, and in particular, that of the BBC. Due to the challenges brought about by globalisation and the politicians' failure to bring answers to some of the citizens' problems - unemployment being one of the most acute - these productions represent a means of exonerating authorities rather than discrediting them. Since, in a globalised world, the State cannot be held fully responsible and accountable for all scourges, these fiction films are meant to highlight the irrational and uncontrollable dimensions found therein.. "It is in fiction that the Gods survive and viewers, many centuries after the Greek tragedy, can experience at once the feeling of finiteness and of infinity." ${ }^{24}$ Gérard Leblanc refers here to mythology, a form of fiction which provides meaning but which also teaches man to accept life and death as existential paradigms.

Yet, the explanations offered by these fiction films are specious on two counts. Firstly, they shift the problem from the origins to the consequences, thereby overshadowing 
the elements necessary for a rational analysis. Secondly, they urge viewers to accept and relinquish possible control over the course of events.

\section{What place for reality?}

31 The main shortcoming of a fiction film like The Day Britain Stopped is the inextricable mixture of elements extracted from the real and from the imaginary worlds. Unlike Peter Watkins, Gabriel Range opts for entertainment with journalism as a mere foundation.

The choice of a highly emotional subject represents, in itself, a major handicap that requires a lot of rigour in the selection and in the processing of the information content. Yet, Gabriel Range fails to be reassuring on this particular point and he juxtaposes images of existing people and images of fictional characters thus undermining the credibility of his message. This situation is all the more surprising and disquieting when we think of the fact that, some years ago, Peter Kosminsky, a major British filmmaker, was forced to justify the creation of a fictional and minor character ${ }^{25}$ in The Government Inspector (2005), a dramadoc ${ }^{26}$ that recounted, with relevance and thoroughness, the affair of the Iraqi dossier sexed up by the Prime Minister's spin doctors to convince British parliamentarians of the appropriateness of an intervention in Iraq. In The Day Britain Stopped, Gabriel Range places side by side two of the main characters of his tragedy though they do not belong to the same world: Mick Rix, the general secretary of the ASLEF at the time, and opposite him a fictional character, Tom Walker, in charge of embodying, the then Junior Transport Minister. While Peter Kosminsky was legitimate in deciding to invent a fictional character that synthesised information, which a 106-minute fiction film would not suffice to provide, Gabriel Range's choice to place side by side two major characters from different worlds disqualified the contents of his message: how can viewers know whether the statements are fictitious or verbatim? This is particularly disquieting with the character of Tom Walker: how far do his statements match the Ministry of Transport's position at the time? How can one be certain whether they do not entirely come from the imagination of the scriptwriter? If dialogues were invented, how can the filmmaker justify the use of images of Mick Rix from existing TV news archives?

The message the director wishes to convey is completely blurred. The only tangible reality that remains at the end of the film is the violence of shocking images edited with a staccato rhythm and which have failed to inform viewers on how the crisis among transport workers got started and how it was solved.

In addition to its reactionary political viewpoints, trade unionists being described as a privileged class, this film fails to go beyond simulacrum and semblance, a criticism often levelled at the If ... series.

\section{The If ... series}

The If ... series offered the $\mathrm{BBC}$ the opportunity to return to the formula of the topicdriven evening, emblematic of examination television, a form of journalism the main characteristic of which is the broadcasting of a fiction film at a prime-time slot followed by a live debate among experts. The topic-driven evening is divided into 
several stages, the first one, a fiction film, being entertaining, informative, and rich in content, and the final one being a late-night debate which brings the treatment of the subject to a close. The initial aim was to present the audience with a state-of-the-art review of the knowledge available on a given topic. Docudrama offered an attractive narrative structure even though, from the point of view of the programme's creators, the term "drama-documentary" seemed more appropriate since a premium was put on the information provided rather than on fiction. By using a label that dated back to the 1960s and was reminiscent of Ken Loach's and Peter Watkins's main films - Cathy Come Home and The War Game - the authors of the series attempted to turn their work into political fiction. The series highlighted the futuristic dimension of potential threats although, when reading the titles of the episodes, ${ }^{27}$ it becomes obvious that the purpose was to familiarise viewers with issues that were looming large.

Most of the actions take place in a relatively near future - half a decade, on average which creates increased tension because it means dealing with an issue that, according to probable scientific projections, is likely to arise and to affect viewers in the course of their lifetime. The time frame, the sequence of events and the issues related to time in general, are key elements: too pessimistic a scenario, one pretending that the tragedy may occur tomorrow, would jeopardize and even condemn the film on account of its lack of credibility; likewise, too distant a deadline would likely diminish the feeling of impending doom both inherent in the tragic dimension of the film and necessary to build tension and prompt viewers to realise that stakes are high. The concept behind the programme, despite the channel's claims, is not so much the "If " as it is the "When", turning the programme into a mixture of both anticipatory and apocalyptic elements. The If ... series was far from being prescriptive. It cashed in on the probability that such events would occur; it was premonitory. Unlike Peter Watkins's films, which were both political diatribes and remedies designed to help citizens face the challenges of their time, these productions were trivialisations of current issues, a conclusion drawn from the fact that all the themes were developed along identical scenarios, something which failed to give much substance to any of them and made them all banal.

The first three BBC productions, between 2002 and 2004 - Smallpox (2002), The Day Britain Stopped (2003), Dirty War (2004) - were used as prototypes, designed to test a formula that later became the If ... series. The If ... series was broadcast in the context of a public television network that, more than ever, needed to prove its worth with a view to the renewal of its prerogatives in 2006. For public television, the formula proved a rich seam into which it tapped extensively, and which allowed it to shoot a dozen episodes in two years.

The broadcasting of the first instalments on Wednesday evenings was not a coincidence and echoed the time chosen, between 1964 and 1970, for the broadcasting of The Wednesday Play, which would accommodate works of all genres even though the most memorable ones, the ones which have gone down in the history of television, were docudramas..$^{28}$ Wednesday evening is a special moment on British television, much sought after by programmers. It allows for the broadcasting of programmes that boost viewers' loyalty pending the moment when viewing figures are the highest: the weekend. This phenomenon was observed early in the history of television and, as soon as competition was introduced - 1955 and the inception of ITV - Wednesday became the day when channels would host a large number of prestigious programmes, stoking 
the rivalry between the public and the private sectors, with a view to achieving loyalty. Intended to fit into the ethics of public television, the If ... series served to convey information on current topics to a large audience, the two main ingredients of this recipe for success being the conjunction of the appropriate day and time for the broadcasting with the choice of an attractive genre. For programme makers, for example, under no condition would the question of embryonic therapy be tackled with an esoteric documentary reducing the programme to the explanations of scientists that images, extracted from microscopes, would adorn: the subject had to be presented in such a way that the broadest viewership would be carried along.

Exhaustive in its intentions, this series intended to review scientific developments but also the sociological, economic and legal consequences of each of the topics it addressed. It allowed the $\mathrm{BBC}$ to position itself as public service television that educated and informed people while entertaining them at the same time.

\section{The If ... series or Investigative TV vs Examination TV}

Up until the inception of the If ... series on public television, docudrama was very rarely followed by a post-broadcast debate and, before the early 2000s, the corresponding films would fall into the category of investigative television. This meant that filmmakers would undertake research and analyses about information previously treated by news and current events, and would present them in a personal and original way. The investigations, which resulted from field surveys among the people concerned and from the cross-checking of various pieces of information, served to highlight a different view or one hitherto insufficiently publicized. These auteur films dealt with subjects that had been treated extensively in the news in the recent past and adopted a perspective that was often voluntarily biased. The temporal distance from the events explained why a television repeat, or even a first broadcast following a period of censorship (ex: The War Game produced in 1965 but broadcast in 1985) would often become historical artefacts that reflected the approach of the subject at the time rather than a relevant point of view. Censorship and delayed broadcasting would rob the programme of its critical dimension.

With the If ... series, the BBC moved away from investigative TV to examination TV. Investigative television, which favoured reportages with journalists who would move to the scene of the events, was gradually replaced by examination television, or the television of experts, with the studio as the place where things happened. The programme substituted issues for events, either social or political, and the reporter disappeared, replaced by specialists. It is in this context that the political and societal debates would take place, on sets, where experts were given the floor. The investigative television of the $60 \mathrm{~s}$ and $70 \mathrm{~s}$ - centred around a fiction film that resulted from thorough investigation and which, by presenting the plurality of opinions, allowed for the search and expression of truth - gradually made room for the television of experts with radically different rules. On TV, these experts exchanged views they previously had the opportunity to highlight in their capacity as consultants for the films aired minutes earlier. This was the case for Danny Kushlick, director of the Transform Drug Policy Foundation, who appeared in If ... Drugs Were Legal (2005) and who was one of the guests during the debate that followed the airing of the film. Rather than exchanging 
views, experts would come to fight for their interests, as they were already familiar with the arguments of their peers on the opposing side.

As for the docudrama itself, it was no longer political work but an alibi for engaging the attention of viewers in the early part of the evening and to absorb them in a theme that was debated throughout the whole evening. Unlike the type of docudrama practised by Peter Kosminsky, for example, the purpose of which is to arouse controversy on recent news on prime-time TV with the presentation of a counter investigation, the If ... series turned a social issue into a trivial topic.

These highly emotional programmes would deal with mankind's survival as a group but also as individuals, in the context of some aberrant individual practices, addiction, whatever type, being one of them. Television would lend itself to themed evenings and the chosen topics would give coherence to all the evening's broadcasts: while a theme like If ... The Toxic Timebomb Goes Off may have caused anxiety, If ... TV Goes Down the Tube was likely to feature both a lighter and more social touch. As for If ... We Do not Stop Eating, it had a potentially much lighter theme which may have been suited to more savoury filmic treatments. Yet, docudramas that introduced these thematic evenings borrowed heavily, stylistically, from investigative television. All the fiction films from the If ... series, along with the three disaster movies that preceded them, tapped into the processes pertaining to investigative journalism, such as proximity and spontaneity, effects elicited by hand-held cameras and the use of disruptive background sounds that would saturate the soundtrack.

However, unlike the political and controversial docudramas, which are highly exposed to litigation and require journalistic accuracy, the doomsday fiction films, as well as those presented in the context of the If ... series, are prone to inaccuracies since their aim is firstly to impress and entertain viewers. Everything is done to hold viewers captive until the end of the thematic evening. Scheduled on primetime, these fiction films obey the constraints of pure entertainment. Consequently the nature and value of the film are profoundly affected. Instead of an auteur film, viewers are confronted with a timely command whose purpose is only to give an overview of the topic.

The quality of the fiction does not lie in its aesthetic nature nor in a specific structure but in the content of the arguments put forward by the specialists who are the only qualified mediators of a television of experts. This is something the executives in charge of the programmes highlight by advertising the exceptional panel of British and foreign professionals but also, as in the case of If ... Drugs Were Legal (2005), of experts from other domains: on the evening the film was broadcast, Emma Bonino, former EU humanitarian affairs commissioner, was live from Brussels. In their intentions, the designers of this programme wanted it to be neutral to give viewers the impression that they had all the required elements to form an opinion.

The specialist must then act as a journalist or a storyteller and must be able to account for his experience and his knowledge, that is to say, to cast over them a look that is both analytic and narrative. The scientist must be able to speak about his subject in both scientific and sociological terms since today's television is defined as a remedial tool; it must be able to act on the viewers' behaviours by helping them understand the economic, political, and sociological perspectives of the issue. The expert, as a consultant or as a participant in the discussion following the film, then morphs into a pedagogue. 
47 As the ultimate example of the BBC's professionalism, the debates of the If ... series were moderated by journalists - Jeremy Paxman acting as host on the evening of the broadcasting of If.. Drugs were Legal - and were accommodated within the larger framework of Newsnight, the evening news programme. This example illustrates the deviance of journalism, which at the end of the $20^{\text {th }}$ century shifted from the transmission of information - Newsnight being emblematic of it - towards forms of infotainment centred on a single subject and in which the journalist-presenter would stand at the centre of a panel of experts. This hybridization of genres is one of the latest developments in television induced by reality TV. The words of the expert have to be dramatic, and the way things are presented is of utmost importance. Dramatization becomes the main tool for the delivering of scientific information which, to be understood, must first be attractive. Scientists are rarely actors and managing speeches and transitions befalls the presenter who leads the debate and, above all, speeds up its rhythm when it becomes too slow or too complex. All the eloquence and pugnacity of a journalist like Jeremy Paxman were required to reach and maintain tension on a subject, in this case drug-addiction, which, because of its chronic character, had no direct connection with the then current events.

On such occasions, the night edition of the news does not exactly comply with the usual news conventions: it adopts infotainment conventions instead and focuses on the theme of the film previously aired; it then becomes a form of advertising designed to elicit loyalty.

By devoting a whole evening to an issue, TV also succeeds in turning a recurring one into a current event, which somehow means distorting the original assignment of journalism. Yet, rather than a perversion of the original journalistic intentions, it is a strategy. These programmes, because they span different genres, be it fiction, documentary or reportage, are designed as attempts to stem the declining audience of investigative journalism, which is significantly losing momentum and was recently either wiped out completely or, in the best of cases, moved from early evening slots to late night ones. The decision not to extend beyond 1998 World in Action, the structure set up by ITV in 1963, aptly testified to this trend. As for Panorama, the equivalent public television formula since 1953, it moved, between 2000 and 2007, from 8:10 pm to 10:15 pm, which significantly reduced the claims it made to inform a large audience. ${ }^{29}$

At this stage, it is worth noting that examination television fails to rid itself completely of the weight and impact of investigative television, viewed by journalists as the only legitimate form of TV journalism. The If ... Drugs Were Legal programme (2005), for example, was built around a detective story: an agent from ofdrug (a narcotics monitoring agency), aided by a former narcotics police officer, carried out an investigation designed to shed light on the accidental deaths of two girls. The structure of the police investigation is very popular and sits well with the hybridization of genres since it is a format that has been repeatedly used, whether in fiction with an educational value, as is the case of the If... series, or in documentaries like those on history, which the $\mathrm{BBC}$ has come to specialise in.

51 The police investigation format provides an easy narrative matrix, which offers viewers the impression of gradually participating in the discovery of the solution. Moreover, it fuels the myth that everything can always be explained, thanks, among other things, to science. Unlike the pedagogical use of hybridisation made by TV in the past, with directors like Peter Watkins and Ken Loach, it is not meant to draw the viewers' 
attention to an aesthetic, which would be denounced as reactionary, but it is intended to facilitate the appropriation of the contents, thanks to a form that is easily accessible. Originally, this approach called for the active participation of viewers, which was an early form of interactivity, a mode nowadays extensively used by reality television. In addition to questions that viewers are encouraged to ponder over before and during the debate, television channels have, of late, increasingly extended exchanges with forums on the internet after the airing of the film. The link this type of programme weaves with viewers is proven by the abundant exchanges each broadcast generates on the internet.

\section{Conclusion}

The If ... series is a paragon of journalistic hybridity combining elements from investigative journalism and others from examination television. While it allowed the $\mathrm{BBC}$ to stem competition from reality television programmes that were rife on private channels at the time and that would garner wide audiences, it also raised denigration and disparagement on the grounds that it provided mediocrity through productions, which distorted, rather than explained, the topics selected.

Due to its obsession with ratings and its need to compete with privately owned channels, the $\mathrm{BBC}$ has given in to the worst forebodings with programmes designed to challenge reality television. It has lately failed to compete with Channel 4 for the best films television can boast of - namely Peter Kosminky's The Government Inspector (Channel 4, 2005), Britz (Channel 4, 2007) and The Promise (Channel 4, 2011) - and has largely contributed to the distortion and the belittling of the genre of the docudrama which talented filmmakers like Peter Watkins and Ken Loach promoted. Finally, it has helped pave the way for infotainment which has gradually taken over from educative and informative programmes.

The compulsion the $\mathrm{BBC}$ feels to remain at the cutting edge of innovation leads it to use modern means of communication to keep in touch constantly with its audience, in particular after the broadcasting of its programmes. Unfortunately, this tendency is likely to increase the dumbing down of issues rather than raise the level of public debate.

\section{BIBLIOGRAPHY}

Bennett Tony, Susan Boyd-Bowman, Colin Mercer and Janet Woollacott. Popular Television and Film. A Reader. London: BFI Publishing/Open University Press, 1984.

Bignell, Jonathan. "Docudrama as Melodrama: Representing Lady Diana and Margaret Thatcher." In Frames and Fictions on Television: The Politics of Identity Within Drama, edited by Bruce Carson, Margaret Llewellyn-Jones, 17-26. Exeter: Intellect Book, 2000. 
Coles, Gail. “Docusoap: Actuality and the Serial Format.” In Frames and Fictions on Television: The Politics of Identity Within Drama, edited by Bruce Carson, Margaret Llewellyn-Jones, 27-39. Exeter: Intellect Book, 2000.

Beattie, Keith. Documentary Screens: Non-Fiction Film and Television. Basingstoke and New York: Palgrave Macmillan 2004.

Brandt, George W. British Television Drama in the 1980s. Cambridge: Cambridge University Press, 1993.

Caughie, John. Television Drama, Realism, Modernism and British Culture. Oxford: Oxford University Press, 2004.

Corner, John. "British Docudrama: Origins and Developments." In Why Docudrama? Fact-Fiction on Film and TV, edited by Alan Rosenthal, 35-47. Carbondale and Edwardsville: Southern Illinois University Press, 1999.

Corner, John. Documentary and the Mass Media. London: Edward Arnold Publishers Ltd, 1986.

Corner, John. The Art of Record. A Critical Introduction to Documentary. Manchester and New York: Manchester University Press, 1996.

Corner, John. "Documentary in a Post-Documentary Culture? A Note on Forms and their Functions”. http://lfbxmljy.blog.sohu.com/176601804.html < accessed on January, 12, 2013” Corner, John and Kay Richardson. "Documentary Meanings and the Discourse of Interpretation." In Documentary and the Mass Media, edited by John Corner, 141-153. London: Edward Arnold Publishers Ltd, 1986.

Creeber, Glen. Tele-visions: an Introduction to Studying Television. London: BFI, 2006.

Deans, Jason. “Kosminsky Defends Docudrama." In Media Guardian, October 17, 2005. Accessed on January 12, 2013. http://www.guardian.co.uk/media/2005/oct/17/broadcasting2

Edgar, David. ‘Theater of Fact: a Dramatist's Viewpoint.” In Why Docudrama? Fact-Fiction on Film and TV, edited by Alan Rosenthal, 174-188. Carbondale, Edwardsville: Southern Illinois University Press, 1999.

Currie, Tony. Concise History of British Television: 1930-2000. Tiverton: Kelly Publications, 2000. Deleuze, Gilles. L'Image-temps. Paris: Les Éditions de minuit, 2014.

Fielding, Raymond. The March of time, 1935-1951. Oxford: Oxford University Press, 1978.

Fournier, Georges. "British Docudrama”, InMedia , 3 / 2013 [Online], accessed on June 1 $1^{\text {st }}, 2019$. URL : http://journals.openedition.org/inmedia/591

Hill, Annette. Reality TV Key Ideas in Media \& Cultural Studies. London: Routledge, 2014.

Holmes, Sue and Deborah Jermyn. Understanding Reality Television. London: Routledge, 2004.

Kilborn, Richard and John Izod. An Introduction to Television Documentary: Confronting Reality. Manchester: Manchester University Press, 1997.

Leblanc, Gérard. Scénarios du réel, Tome 2. Paris and Montréal: L’Harmattan, 1997.

Lebow, Elisa. "Faking What? Making a Mockery of Documentary." In F is for Phony: Fake Documentary and Truth's Undoing, edited by Alexandra Juhazs and Jesse Lerner, 223-238.

Minneapolis: University of Minnesota Press, 2006. 
Lipkin, Steven N., "Defining Docudrama: In the Name of the Father, Schindler's List and JFK." In Why Docudrama? Fact-Fiction on Film and TV, ed. Alan Rosenthal, 370-385. Carbondale, Edwardsville: Southern Illinois University Press, 1999.

Lipkin Steven N., Real Emotional Logic: Film and Television Docudrama As Persuasive Practice, Carbondale: SIU Press, 2002.

Paget, Derek. "Codes and Conventions of Dramadoc and Docudrama." In The Television Studies Reader, edited Clyde Allen Robert and Annette Hill, 196- 209. London: Routledge, 2004.

Paget, Derek. "'Cathy Come Home' and 'Accuracy' in British Television Drama." New Theatre Quarterly vol. 15, issue 1 (February 1999): 75-90. Cambridge: Cambridge University Press, 1999.

Paget, Derek. "Tales of Cultural Tourism." In Why Docudrama? Fact-Fiction on Film and TV, edited by Alan Rosenthal, 47-64. Carbondale and Edwardsville: Southern Illinois University Press, 1999.

Paget, Derek. No Other Way to Tell It. 1998. Manchester: Manchester University Press, 2011.

Paget, Derek. True Stories? Documentary Drama on Radio, Screen and Stage. Manchester: Manchester University Press, 1990.

Rosenthal, Alan and John Corner. New Challenges for Documentary. Manchester: Manchester University Press, 2005.

Schlesinger, Philip. Putting "Reality” Together. London and New York: Routledge, 1987.

Sempéré, Hélène. "Peter Watkins : L'Écriture du présent ou l'aporie de la représentation." TRANSn³, 2007. https://trans.revues.org/176, site accessed June $2^{\text {nd }}, 2018$.

Winston, Brian. Lies, Damn Lies and Documentaries. London: The British Film Institute, 2000.

\section{ENDNOTES}

1. British producer, responsible for acclaimed documentaries, among which Smallpox; Silent Weapon, 2002.

2. "We began production on Smallpox 2002 in February 2001.'This is not science fiction', had been our mantra, this could happen. This film is not about a distant future, it's about tomorrow. Suddenly, seven months later, bioterrorism became a reality and Smallpox 2002 acquired the kind of prescience it had never sought."

http://www.bbc.co.uk/drama/smallpox2002, site accessed June 2, 2018.

3. A famous example was the anthrax attacks in the USA which took place shortly after the Word Trade Center attacks of September 11. "Spore-laden letters were posted on September 18 and October 9, 2001, to media organisations in Florida and New York, and to the offices of Tom Daschle, then the Senate Democratic leader, and a colleague, Senator Patrick Leahy. Five people were killed and another 17 became ill due to the attacks". Ibidem.

4. Great Britain Parliament. House of Lords: Select Committee on the BBC Charter Review (2005, London: The stationary Office), 45.

5. "The fundamental strengths of the licence fee will persist in a fully digital world. So while the BBC accepts that a future Government may return to the question of BBC funding, it must also recognise that the licence fee is an integral element of what makes the $\mathrm{BBC}$ what it is: independent, universally available and focused on the public interest." Review of the BBC's Royal Charter, May 2005. 
<http://downloads.bbc.co.uk/aboutthebbc/insidethebbc/howwework/reports/pdf/ green_paper_response.html>, official site of the BBC, accessed on June 2, 2018.

6. "Bush requests BBC Smallpox 2002: Silent Weapon drama. US President George Bush has requested a copy of BBC Two's Smallpox 2002 programme after a leading scientist told him about the making of the drama." $<\mathrm{http} / / /$ news.bbc.co.uk/1/hi/entertainment/tv_and_radio/1804688.stm>, official site of the BBC accessed June 2, 2018.

7. "In the UK the show has been hailed a ratings success after 3.4 million viewers tuned in." BBC News, February 6, 2002.

8. For information on docudrama - "a hybrid form, wedding 'documentary' material with 'drama"' - and the subgenres, see Steven N. Lipkin, Real Emotional Logic: Film and Television Docudrama As Persuasive Practice (2002, Carbondale: SIU Press), 1

9. Annette Hill defines reality television as "a container for a range of diverse programmes, series, formats and events in which elements of documentary, talent shows, talk shows, soap operas, melodramas and sports mix together to produce sub-genre." Annette Hill, Reality TV Key Ideas in Media \& Cultural Studies (2014, London: Routledge), 184.

10. Originally put off to a later time, it was finally released by $B B C 2$ on 31 July 1985 , for the fortieth anniversary of the Hiroshima bombing.

11. "Transmission was cancelled for fear of traumatising audiences", see Sarah Barrow and John White, Fifty Key British Films (2012, London: Routledge), 143.

12. Realism refers to the impression viewers have that what they are watching is actually what happened and was recorded by the camera, producing an impression of reality. For more details on this point, see Jacques Aumont, Aesthetics of Film (Austin: University of Texas Press, 1992), 121-126.

13. http://pwatkins.mnsi.net/warGame.htm, accessed January $9^{\text {th }}, 2019$.

14. The last Friday before Christmas.

15. See TV series like Hatufim and Homeland.

16. British train drivers' trade union.

17. This statement is supported by the broadcasting - on September 14, 2005 - of 7/7: Attack on London, just nine weeks after the explosion of several bombs in the heart of London on July 7 , 2005. Unlike The Day Britain Stopped, this programme was broadcast on a channel with a restricted viewership - Channel 5 - which deprived it of a truly national audience. It was co-directed by Jo Burge and James Erskine and produced by Mentorn, a company which owes its fame and fortune to reality TV programmes.

18. Philosopher and a major post-modernist theorist.

19. Gilles Deleuze, L'Image-temps (Paris: Les Éditions de minuit, 1985), 33.

20. For details on Peter Watkins's metaleptic disruptions, see Hélène Sempéré, Peter Watkins : L'Ecriture du présent ou l'aporie de la représentation. https://trans.revues.org/176, site accessed June $2^{\text {nd }}, 2018$.

21. In 2003 the British Parliament approved of the invasion of Iraq on the false claim that Iraq could deploy weapons of mass destruction within 45 minutes.

22. The process which consists in making people believe that things are natural.

23. Gérard Leblanc, Scénarios du réel, Tome 2, (Paris and Montréal: Éditions L'Harmattan, 1997), 96. Translation of the quotation from the original text into English by the author of this article.

24. Gérard Leblanc, Scénarios du réel, Tome 2, op.cit., 95. Translation of the quotation from the original text into English by the author of this article.

25. Qasim Hamdani.

26. While the scenarios of docudramas are loosely based on actual events, the ones of dramadocs strictly respect factualities.

27. Series 1 
If... The Lights go Out, 10 March 2004

If... Things Don't Get Better, 17 March 2004

If... The Generations Fall Out, 24 March 2004

If... Women Ruled The World, 31 March 2004

If... We Don't Stop Eating, 7 April 2004

Series 2

If... Cloning Could Cure Us, 16 December 2004

If... We Could Stop The Violence, 22 December 2004

If... Drugs Were Legal, 12 January 2005

If... TV Goes Down the Tube, 21 March 2005

http://news.bbc.co.uk/2/hi/programmes/if/default.stm, site accessed on May 30 $0^{\text {th }}, 2019$.

28. For BBC's top twenty films, see the British Film Institute's official website

British Film Institute

:

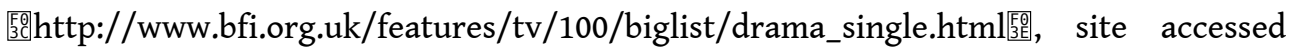
June $2^{\text {nd }}, 2018$.

29. "Panorama returns to peak time on BBC ONE". BBC Press Office, 18.07.2006.

http://www.bbc.co.uk/pressoffice/pressreleases/stories/2006/07_july/18/panorama.shtml, site accessed June $2^{\text {nd }}, 2018$.

\section{ABSTRACTS}

This article examines the evolution of disaster films and series broadcast by the BBC in light of major developments in the British televisual landscape, such as the competition for higher TV ratings and the ever-increasing criticisms, by private operators, of the BBC's monopoly on the license fee. How far have these issues influenced TV productions? Why did films originally designed to educate and inform the population about potential dangers, for example the military use of nuclear power - Peter Watkins's The War Game, 1965 - gradually evolve towards phobocratic series, like the 2004 If ... series? It would be shortsighted to put the blame on the BBC's need to attract a larger audience only; instead, special attention will be paid to political reasons that may account for the public broadcaster's recent decision to promote disaster films.

\section{INDEX}

Keywords: Television, quality TV, disaster films, series, politics

\section{AUTHOR}

\section{GEORGES FOURNIER}

Georges Fournier is Professor at the Department of Foreign Languages of the University of Limoges. His main research interest lies in British authored television. He has published many articles on political docudrama and is currently conducting research in factual programming. 